\title{
Mary's Reincarnation and the Banality of Salvation: The Millennialist Cultus of the Lady of All Nations/Peoples
}

\author{
Peter Jan Margry \\ Meertens Institute, Royal Netherlands Academy of Arts and Sciences \\ PO Box 94264 - 1090 GG Amsterdam, The Netherlands \\ peterjan.margry@meertens.knaw.nl
}

\begin{abstract}
This article deals with the transnational Dutch-Canadian apparitional cultus of our Lady of All Nations/Peoples. It analyses how contemporary visionary Catholicism is influenced by religious eclecticism, esotericism, and New Age spiritualities, and how this devotion has shifted into an autonomous millennialist movement. Finding fertile soil in modern societies in socio-economic, political, and religious crisis, and due to the dwindling of existential certainties at the individual level, its ideology of "progressive millennialism" has shown itself to be a successful religious format that mobilizes devotees, even when its deviation brings the movement into conflict with the formal Church. The movement's prophetic and millennialist views fit into a salvific system of conditionality according to which the visionary, unveiled as the reincarnation of Mary herself, will realize the new millennium if her party will fulfill certain conditions. With its new theology the Quebec movement tries to appropriate the whole Lady cultus as a vehicle for universal salvation. In this way the means for revelation and salvation are taken from the hierarchical ecclesiastical powers-that-be and situated in the "banality" of the everyday life of the reincarnated Mary. In the providential Marie-Paule Giguère, the devotees involved find an appealing prophet who is both Mary and a co-redeeming messiah, and who in the near future is supposed to realize the second millennium, framed in a new, modern cosmology, for all peoples and faiths.
\end{abstract}

\section{Keywords}

apparitions, Mary, millennialism, eschatology, sects, Amsterdam, Quebec

Ethnographic fieldwork comes with surprises. A scholarly conference in Quebec, Canada, gave me the opportunity to make a visit I had been 
looking forward to for a long time. I knew from my research that in the small town of Lac-Etchemin, sixty miles from Quebec City, an outstanding marvel of modern religious culture could be found. Of course, like most marvels, it is also a strongly disputed one. What I hoped to encounter there was the acclaimed reincarnation of the mother of Jesus, of Mary herself. Mary allegedly resides there as the Lady of All Peoples, under the worldly name of Marie-Paule Giguère. ${ }^{1}$ From her international headquarters in town she writes her prophetic scriptures and guides and coordinates her adherents, organized in a salvific Army of Mary. The congress would provide me an opportunity to meet this Lady whom I seemed to have studied in various appearances at all kinds of contested Marian shrines all over the world. This was a chance to interview her about her mystic, prophetic, and enigmatic messages.

This would indeed have been the case were it not that just days before my arrival, six nuns from her Army of Mary, those living in a convent in Hot Springs, Arkansas (USA), had been excommunicated by the Roman Catholic Church (De Millo 2007), as a consequence of a declaration by the Vatican in which the movement was declared schismatic and its teachings heretical. ${ }^{2}$ The vexing events turned the spotlights of CNN and other networks and media on the town of Lac-Etchemin and brought the headquarters of Mary's supportive troops to full alert, shielding the aged Marian reincarnation and making her inaccessible to everyone outside her inner circle.

Fortunately, when I arrived to check the beleaguered headquarters, the Spiri-Maria, as their religious complex is named in a new-agey way, was neither closed nor fenced off. The Spiri-sister with whom I had previously been in correspondence — Giguère's Flemish right hand Chantal Buyse - was willing to receive me. However, I did not manage to get any explanation of the enigmas regarding Marie-Paule's

\footnotetext{
1) Since the 1980s Marie-Paule has sometimes also confusingly named herself as Mère Paul-Marie and published under that name; a foundation under that name has also been established, for moral support to other organizations and to stimulate priestly vocations.

2) Declaration of the Congregation for the Doctrine of the Faith, July 11, 2007. This declaration follows in part earlier disqualifications by the Archbishop of Quebec of March 26, 2007, and the Conference of Catholics Bishops of Canada of June 29, 2001.
} 
theology, redemptive prophecies, and eschatological views. Instead, to avoid any form of her own interpretation, she simply referred me to Marie-Paule's "holy" scriptures. Marie-Paule's "revelation" consists of a series of fifteen volumes called Vie d'Amour (Life of Love), an autohagiographical corpus of thousands of pages, dealing with her life story and mystical experiences. ${ }^{3}$ Reading Theresia of Lisieux's inspirational L'histoire d'une âme (The Story of a Soul) and being active as a writer for journals made Marie-Paule think of putting her life to paper (MariePaule 1979, 1:296). In 1958 her spiritual leader told her to commence. The text was said to be partly dictated by the Lord himself, not by means of voices or apparitions but by a communication, as she stated, "from spirit to spirit," initially at the "level of the heart" and later at the level "of the head," underlining in this way their concurrence. The books form the paradigm and the underpinning of her concept of the Lady of All Peoples and her role within the divine salvific plan. It ultimately also positions Giguère as the embodied appearance of the Lady of All Peoples, one who is part of a new Marian Trinity. For the Church it proved to be a classic example of how visionary revelations incline to deviancy (Laurentin and Sbalchiero 2007:1276), and for the public administration it was again a warning of the dangers of sectarian religious movements (Geoffroy and Vaillencourt 2001:136-141). In the context of the transnational devotion of the Lady of All Peoples, I will analyze how the prophetic and millennialist visionary views are instrumentalized to claim the whole cultus as a vehicle for universal salvation and, as a consequence, lead the Marian movement almost inevitably into divergency and contestation (cf. Margry 2004).

\section{Quebec and Amsterdam}

The Lady of All Peoples was not initially a Canadian apparition, however, but one that originated in the Netherlands. Toward the end of the Second World War, on March 25, 1945, the Virgin Mary intervened in

3) The textual corpus describing her life and experiences over the period 1920-1980 was published in 1979 and 1980, and reprinted in 2001. It was supplemented in 1992-1995 by a ten-volume continuation over the period 1980-1993, partly consisting of picture books documenting and illustrating the events from 1920 on. 
the occupied Netherlands with a veiled message about the approaching end of the Nazi regime, the then-raging famine, and the World War in general. ${ }^{4}$ The thirty-nine-year-old, unmarried visionary Ida Peerdeman (1905-1996) saw in her home a sea of light from which a woman emerged, who, in response to Peerdeman's question of whether she was Mary, answered, "They will call me the Lady." The few words that the apparition then spoke contained some of the newly-developed theological concepts that would be further expanded in her following fiftyfive messages, including a new universal Marian prayer and a new name or title of Mary as "the Lady," who is said to be the "Mother" of all Nations, or as she was named later in the Québecqois cultus, Lady of all Peoples. ${ }^{5}$ The central meaning of the Amsterdam apparitions is reflected in the contents of the messages about what will happen in the future regarding the Church, mankind, and the redemption.

March 1945 was thus the beginning of two long series of apparitions and messages, ending in May 1959. The first twenty-five messages are primarily characterized by eschatologically-phrased prophecies on disasters, war, chaos, and diseases, and implicit warnings against lovelessness, atheism, degeneration, and modernism, all elements standing in a historic line with the Marian apparitions and messages of Fatima (1917) and La Salette (1846). Amsterdam, however, elaborates on them. Amsterdam is not just one of the mere Cold War anti-communist apparitions of the post-war religious revival; Mary also brought there a positive message (cf. Kselman and Avella 1986:419). In repeated prophecies the Lady promises to save the world and mankind. She also expresses an urgency to do so, since "all peoples are groaning under the yoke of Satan." If and when humanity were to achieve the conditions the Lady set out, her prophecies on the horrors would not come true,

4) For the Amsterdam apparition and its devotional praxis, see Alles 2008; Kruk 2003; Lemm 2003; Margry 1997, 2009a, 2009 b.

5) In the apparitional Amsterdam cultus Mary initially identified herself in 1945 only as "Lady" and "Mother." It was only in 1950 that she revalued her name with the addition "of all Nations," which is in the original Dutch Vrouwe van Alle Volkeren. Shortly after this the name was translated into English as "Lady of All Nations," which is still the common translation in Amsterdam. The later "Quebec" translation of Volkeren to "Peoples" is the most literal, but it has never been introduced into the Amsterdam cultus, to avoid the suggestion of a connection with the "false" movement in Quebec. 
but: "I am warning the peoples of the world. The time is serious and pressing. The Church of Rome now has her chance" (Messages 1999: 115). She refers also to the present-day degeneration of Church and society, especially in the Netherlands where "modern humanism, realism and materialism" dominate, and to a theological renewal movement that would press for additional restrictions. This kind of conditional prophecy is an example of what has been called "avertive apocalypticism," because its fulfilment is subject to human efforts to match the conditions set forth (Wojcik 2011). But in the context of these specific messages Wessinger's concept of "progressive millennialism," described as the belief "that humans working according to a divine or superhuman plan will progressively create the millennial kingdom," is also applicable (Wessinger 2000; cf. Ashcraft 2011). Because of the redemptive aspects of the Amsterdam messages, "progressive millennialism" is a better characterization of the revelations of the Lady of All Nations.

In 1951, immediately after the promulgation by the Vatican of what is said to be the fourth Marian dogma - the Assumption of the Blessed Virgin - the content of the next thirty-one Amsterdam messages changed dramatically. Instead of chaotic depictions of evil and doom, the new messages became couched in more positive terms and seem to have slowly revealed a new divine plan by which Mary, from that date onward "the Lady of All Nations," will deliver the world and become the Mother of all humankind. On 11 February, 1951, the apparition renounced even her historic name, and to emphasize that, she added to her new name of the Lady of All Nations the clause "who once was Mary." This change was also embedded in a new universal prayer text with which the Lady is invoked as protector against disasters and degeneration. The conditionality of her acting came specifically to the fore when she communicated in 1953 that the prayer, in combination with an expected fifth dogma, would be the main instrument to help save mankind and the Catholic Church (Messages 1999:134). Some months later Peerdeman received the message in which the Lady announced herself as a new universal redeemer, a co-redemptrix next to Christ (Messages 1999:138). The Lady added that this identification should be brought in as a new, fifth dogma in Catholic theology. Because of this universality and "salvific plan," adherents regard the Amsterdam messages as both the termination of the Marian era and the apex of the 
modern sequence of Marian apparitions. This apex was supposed to climax around the year 1954, one hundred years after the promulgation of the third dogma of the Immaculate Conception, when the Lady was supposed to have her title made official. Or, as Mary formulated it, "This time is Our time," meaning that this time the Lady had been sent with her messages across the whole world, addressed to all peoples, and that her salvific role in the modern era is determinative (Messages 1999:105, 145-49). Her prophecies seem to be a preparation for the new millennium. She promises that a millennial reign of Mary and of a new (True or Holy) Spirit is foreseen, and that she will then bring "True Peace" on Earth (Messages 1999:70, 133-134, 166). The year 1954 passed, however, without these claims being fulfilled.

Conversely, two distinct episcopal commissions appointed by successive bishops of Haarlem to investigate the authenticity of the visionary Peerdeman and her messages concluded in 1955 and in 1973 that these phenomena were not from a preternatural source. ${ }^{6}$ They curbed the movement in Amsterdam, but as the apparitions were explicitly directed to the whole world, the devotion, notwithstanding the negative verdicts of the bishops, caught on in other countries (Margry 2009b). Therefore it became a matter for the world church and the Roman Congregation for the Doctrine of the Faith, which subsequently endorsed the negative conclusion, that it is not established that the phenomena are of a supernatural order ("non constat de supernaturalitate"). ${ }^{7}$

In the same period the Canadian visionary Marie-Paule Giguère, born on September 14, 1921, in Sainte-Germaine du Lac-Etchemin, needed to refigure her troubled life. Despite an early wish to live a celibate religious life, she was advised not to do so and to get married. But her marital life proved to be problematic ("a nightmare") and, after

\footnotetext{
6) Analecta van het bisdom Haarlem, May 7, 1956, and March 2, 1973; cf. Alles 2008:29; Margry 1997:166-168.

7) Notifications of the Congregation for the Doctrine of the Faith of March 13, 1957, and of May 25, 1974, the last one published in Analecta van het bisdom Haarlem, August 1974, and in Alles 2008:116-117. The Latin expression leaves the possibility open that maybe in a later stage supernatural status for the Amsterdam apparitions could be established; it does not (yet) imply a final rejection ("constat non"). Ultimately, in 2002, a new bishop of the diocese of Haarlem, in contradiction to all earlier rejections, decided to acknowledge the Amsterdam apparitions.
} 
thirteen years, led to a divorce in 1957 and an out-of-home placement of her five children. ${ }^{8}$ In trying to overcome her trauma while giving a place to the celestial voices she had been hearing since her teenage years, Giguère was drawn more and more into Marian spirituality and devotionalism. Writing down her life story and interpreting the mystical phenomena she had been experiencing, she started to attribute new interpretations and meanings to her life. The expressive titles of the volumes she wrote, like Vie Purgative (Purgative Life), Victoire (Victory), and Vie Céleste (Heavenly Life), give an indication of the process of sublimation she went through.

After participating in a group visit to a small Marian shrine on the edge of Lake Etchemin on the evening of August 28, 1971, MariePaule received an interior revelation confirming the necessity of the creation of an "Army of Mary," starting with some seventy-five likeminded devotees in a new religious community, as an alternative to the Legio Mariae, the lay Marian world association of 1921 in which she had been involved (Marie-Paule 1979, 1:244-256, 301). . Within the context of the chaotic era of the long 1960s her new Army required of members "personal interior reform" with strict devotion to "The Triple White: the Eucharist, Mary, and the Pope," performed in "an authentically Christian way of life" and — then still — in "fidelity to Rome and the Pope." Through the appeal of her messages, and with her charisma and even her vocal capacities, she managed to enthuse her followers and establish a successful grass-roots Marian movement.

Meanwhile in France, Raoul Auclair (d. 1997), a radio journalist and author of books on Nostradamus, apparitions, revelations, and eschatology - nicknamed "The Poet of the End of the Times" - got notice of the Amsterdam apparitions. Already in 1966 he had organized a successful conference on the Lady in Paris, in which he tried to connect the outcome of the Second Vatican Council on Mary to the Amsterdam messages. He even stated that all issues that were brought up during

\footnotetext{
8) Later her former husband, Georges Cliché, made his "way to Damascus,” found consolation, asked for remission, and started a new life within the Army of Mary.

9) The integral Communauté de la Dame de tous les Peuples, consists of five "works:" l'Armée de Marie (Army of Mary), la Famille des Fils et Filles de Marie, la Communauté des Fils et Filles de Marie, les Oblats-Patriotes, and the Institut Marialys; see http://www .communaute-dame.qc.ca/oeuvres/OE_cinq-oeuvres_FR.htm (accessed February 17, 2012).
} 
and around the Council had to be interpreted as a confirmation of what was revealed in the Amsterdam messages (Zimdars-Swartz 1991:256259). The text of the conference was published under the obvious title La Dame de tous les peuples, making him the single major international propagandist for the Amsterdam cultus at that time. The French book found its way to Catholic Quebec and was given to Giguère by a friend. Upon rereading it several times, she recognized the similarities in the messages she and Peerdeman had received and became convinced of the structural connection between the two mystic experiences. This idea ultimately brought Auclair and Giguère into contact with each other in 1971. In those years, with the Church's anathema on the Amsterdam cultus and suppression of its local devotional practice, Marie-Paule's interest in the Lady of All Nations became stronger. The universality of the Amsterdam messages matched her divine promptings and personal ambitions for a global Marian movement at the culmination of the Marian era. The Second Vatican Council seemed in line with that universality, as it strengthened the position of Mary, with Pope Paul VI giving her the title of "Mother of the Church." As a result Marie-Paule wanted to meet the visionary Peerdeman. She went to Amsterdam three times (Lemm 2003:130-135). Her third visit, in 1977, proved to be constitutive for a new sequel to the Amsterdam apparitions and an impetus for shifting the core of the cultus to Quebec. Marie-Paule claimed that during Mass at the shrine in Amsterdam the visionary Peerdeman pointed at her (Giguère) while saying, "She is the Handmaiden." This was understood to be the proof of what was proclaimed in the Lady's fifty-first message, in which Mary announced her return to earth: "I will return, but in public." With this, a recognition of the Lady of All Nations in Giguère was attributed to the visionary Peerdeman, and through this maneuver Marie-Paule retrospectively appropriated the prophesied public return of Mary on Earth (Messages 1999:151). She "hijacked" the devotion in Amsterdam by claiming Lac-Etchemin to be the sole continuation of that cultus, and by using the formal recognition of its supernatural status by the bishop of Haarlem-Amsterdam in 2002 in pursuit of her own purposes. ${ }^{10}$

10) Time and again the bishop of Haarlem-Amsterdam has tried to make clear that the two devotions, notwithstanding their similar names, have nothing to do with one another; that the one in Quebec is "false" and that there is no ground for the assertion 


\section{Quebec and the Vatican}

Perhaps due to a combination of inadvertence and eagerness to support religious initiatives in a time when the Church was in decay, in 1975 Québecqois Cardinal Maurice Roy granted the Army of Mary formal recognition as a Roman Catholic pious association, without doing a proper investigation of the community's stance. As a consequence of this formal acknowledgement by the Church, the movement peaked in the following years. In about ten years the movement, stimulated by its own proselytes bringing a millennialist message, expanded outside Quebec to find some thousands of devotees in approximately twenty countries all over the world. The expanding movement benefited from the perception of a divine endorsement, "proven" by the formal status of the organization, in combination with the growing numbers of new supporters. ${ }^{11}$ The fact that the texts with Marie-Paule's views were not published before 1979 is presumably the main reason that the movement remained under the radar of those charged with checking whether its teachings conformed to the doctrines of the faith. Misled by the formal approbation of the Church, followers did not fully realize the implications of the new teachings when they were published. Beginning in the early 1980s people became increasingly worried after closely reading the first published volume of Marie-Paule's Vie d'Amour. In addition, the regional authorities and media were alarmed by the massive acquisitions of land and building activities of the Army at the edge of the lake, activities that strengthened the idea of an institutionalizing self-supportive sectarian community. ${ }^{12}$ But it was only after a stream of newspaper articles expressing astonishment at what was actually

that Peerdeman would have given Giguère a mission in relation to the Lady of All Nations. See http://www.de-vrouwe.info/en/notice-regarding-the-qarmy-of-maryq-2007. 11) The size of the current movement cannot be calculated precisely. An estimate of 25,000 has repeatedly appeared in newspapers without any source reference. However, the number of committed followers should be estimated, as the movement itself states, at a maximum of "several thousand members" worldwide, but probably less today.

12) André Poulin, "Achats énigmatiques des terrains," in La Voix de Ste-Germaine, January 31, 1984. In 1983, within a short time, several sites were acquired by the Army of Mary at double current prices. Most of the sites were connected with one another. Big investments were being made in order to create a world center for the Army of Mary and its Militia of Jesus Christ. 
professed in Marie-Paule's scriptures that the bishop of Quebec realized his misjudgment and started to take action against these doctrinal deviations. The mystic prose was not focused on God but fully centered around Giguère as a reincarnation of the Lady of All Peoples. Through this terminology it ultimately became clear to the Church that the teaching was not a complement to official Christology or Mariology but a replacement of it by a completely new doctrine. ${ }^{13}$ This realization finally caused the new archbishop of Quebec to decide to withdraw the approval of his predecessor. On May 4, 1987, he declared the movement schismatic and disqualified it as a Catholic association because of its false teachings. ${ }^{14}$ In the Vatican the community's doctrine was declared "heretical." To be completely sure, the archbishop-to-be had asked the top doctrinal watchdog, Cardinal Joseph Ratzinger, to have some of Marie-Paule's scriptures screened by the Congregation for the Doctrine of the Faith. In a brief note of February 27, 1987, Ratzinger, too, concluded that the movement was in "major and very severe error," in particular for the ideas of the alleged existence of an Immaculate Marian Trinity in which Mary is no longer just the Mother of the Son of God but the divine spouse of God. As a consequence, the theological exegesis of Marie-Paule's writing by her theologian Marc Bosquart was likewise condemned. It left the Army seemingly disarmed, forbidden to organize any celebration or to propagate its devotion for the Lady. Priests from the Quebec diocese who became involved would be excluded from their priestly functions, although the penalty of excommunication or condemnation was not yet called for. Despite these measures, the movement did not wind down. On the contrary, its mission continued, with greater conviction of the real truth that had been revealed to them.

The Family and the Community of the Sons and Daughters of Mary, as the movement now calls itself, shows the characteristics of an underground group of religious devotees who have created a closed, supportive, social, and ideological environment. The Community has not only organized itself internally; it has also created semi-independent

\footnotetext{
13) Mgr. Leo Blais in La Presse [Montreal], May 8, 1988.

14) "Au Sujet de l'Armée de Marie." Revue Pastorale Quebec 112, no. 8 (June 26, 2000); Note Doctrinale des Évêques Catholiques du Canada sur l'Armée de Marie; see www.cccb.ca/site/Files/NoteArDeMarie.html.
} 
geographical zones with monastery-like housing facilities in LacEtchemin. It has created what Colin Campbell called a cultic milieu, a habitat hostile to the external world and authorities, where not only ideas arise but also religious practice takes place (Campbell 1972; cf. Barkun 2003:24-26). In the beginning the Army of Mary was seemingly more a new Catholic movement related to the modernization of the Church after the Second Vatican Council. As the role and position of Giguère became stronger, the movement showed more of the characteristics of a sect. A growing distinction between adherents and nonadherents to the Vie d'Amour theology came to the surface, leaving less and less space for individual mysticism. New revelations to the leader of the group, who thus had first-hand experiences with the divine, changed the movement more and more into a cult of a revelatory kind, where the truth is revealed and individual seekers have to become strict adherents (Campbell 2002 [1972]:16-18). However, the Army of Mary is in fact a case that does not fully fit Campbell's concept of cult or cultic milieu. The community has a particularized revealed truth, which only partly rejects the paradigms of the church. It elaborated on the public revelation of the Roman Catholic Church and on fundamental principles, but started to deviate from some of the basic teachings. Giguère and Auclair started to create "stigmatized knowledge," as Barkun called such claims to truth by millennialist or cultic movements (Barkun 2003:26-27). The Army of Mary claim their teachings as verified truth, namely, as mediated by Mary herself and adapted to the modern state of the world, despite their rejection and suppression by the ecclesiastical powers and existing institutions.

There is also another difference. Although Giguère is the divine medium, she was not able to offer a full exegesis on all dimensions of her mystic experiences. Therefore, two "theologians" were found, to systematize and interpret her mystic writings into a more coherent theology and to elaborate her providential role within the whole of Christianity. This development enhanced the group's sectarian character. Although their theology is Christian-based, it integrates millennialist views in combination with heretical theological, gnostic, esoteric, and cosmological teachings (cf. Martel 2010). ${ }^{15}$ When, in addition, in 2007,

15) In this way the Quebec teachings deviate from the apocalyptic and eschatological interpretations by Hans Baum (1970) of the Amsterdam messages, which are highly 
schismatic ordinations to the priesthood took place and Giguère positioned her Quebec "Church of St. John" in opposition to the Roman "Church of St. Peter," the Vatican pronounced a full excommunication of the movement, declaring their doctrines to be heresy. ${ }^{16}$

\section{Millennialist Cosmologies}

The size of Giguère's oeuvre and her style of writing made it difficult to communicate its content to all of her followers, let alone to the outside world. In order to synthesize the prophecies and mystic experiences, she recruited academic and media-trained assistants who were better able to pass on the content and who could take the lead in the international mission of the movement. The death of Auclair's wife in 1977 coincided with this development, which gave him the opportunity of moving to Canada to lecture on the Lady of All Peoples and, because of his eschatological fascination and knowledge, to study Giguère's writings. He took the first step in a mutual recognition of Giguère, with which he attributed symbolic value to her prose and person:

For this is what your Life of Love is: a Configuration, and a Configuration in Mary, the first and the wholly Configured. Hence, those who will read you — and they will no longer be only the rare privileged souls of today — will see God's seal, in prophetic signs, placed upon your woman's life, bearing witness in time to the eternal designs. So if the Lord Jesus Christ imposed upon you the duty of writing your life, it is because He wishes to hold up this narrative, this example and this mystery, to all souls of good will. (Marie-Paule 1980, 12: ch. 42)

Being configured into Mary c.q. the Lady, Giguère attributed a similar but subaltern position to Auclair. She gave him the blessing as a "Son of Mary" and invoked God to "send down on you the fullness of grace

anti-gnostic. Regarding Baum, see Beinert and Petri 1997:86-88. Martel, who focuses on the esoteric components of the Quebec movement, characterizes the ideas of the Army of Mary as the "fabrication d'une gnose mariale," Martel 2010:181.

16) Declaration of the Congregation of the Doctrine of the Faith, July 11, 2007; see www.cccb.ca/site/images/stories/pdf/decl_excomm_english.pdf. It endorsed a similar declaration by the archbishop of Quebec of March 26, 2007, and also sustains an earlier negative "Doctrinal Note" by the Canadian Conference of Catholic Bishops of June 29, 2001. In 2010 the priest Raymond Martel published the critical book La face cachée de l'Armée de Marie, on how the "sect... deceives" its followers. 
so that you may become the greatest theologian of all times." Acting in this reciprocal way, they started to recast and paraphrase Giguère's mystic revelations into the new theology the movement was promised, and attributed divine qualities to the visionary. Drawing on contemporary sociological views, Auclair first pointed out that modern sanctity was no longer to be found in the extraordinary or the elite but in the banal, in the ordinary and daily life of the common people (MariePaule 1979, 1:10). By distancing sanctity from the Churchly paradigm, he prepared the way for the "ignorant" lower-class woman who experienced daily life in all its gruesome facets to become revelatory, sensitive, and receptive. Truth was presented as revealed from the "sincere" and "authentic" grass roots and not from "corrupted" institutions, which is, however, a topos within modern visionary culture. Seen from this perspective, Auclair "canonized" Giguère, emerging from "banality" as an "object of supernatural graces," who with her prophetic gifts was able to light up the darkness of modern times, so that they might become a time for redemption - or more precisely, for co-redemption by Mary, embodied in Marie-Paule. This salvific idea was laid down in her writing - "she knew it, but did not understand it" — and Auclair had to bring in his exegesis to make her theology of the banal understandable to the world (Marie-Paule 1979, 1:12-13).

Marie-Paule gave him the ammunition for that project in her writings. Already at the age of ten she had offered herself to Jesus and asked him to let her suffer equally: "I want to help you carry your cross," and "I also want to share the suffering of Mary" (Marie-Paule 1979, 1:29). These few words reveal her program as the reincarnation of Mary. Her mature life was full of suffering, recorded in such a way as to suggest that it was a "banal" imitative suffering of Christ. She frequently received whispers of support from Jesus and Mary on her victimization, Calvary, and suffering. In 1952, Jesus asked her to share his suffering (Marie-Paule 1979, 1:157). All of these voices and messages from Jesus and Mary are described in seeming anticipation of a predestined assignment, creating the logic of redemption that she appropriated in her later life. During the Holy Year 1950 she had already received the message that "one day it [i.e., the meaning of her suffering] will be all revealed" (Marie-Paule 1979, 1: 120). In 1957 Jesus lifted the veil a bit more by saying, "Have courage my child, still some more time. As you 
must suffer to become Sovereign of Earth, one day." But before that, it was explained that she had to drink the chalice to the bottom and undergo the passion of Christ (1979, 1:266, 286, 322). Jesus also announced she would write her life under the title Vie d'Amour. The sequence of mystic messages came to a crescendo when, in April and May 1958, she received a series of constitutive prophetic messages from God in which he announced the "betrayal" and crucifixion of the "innocent" Marie-Paule by the priestly souls of the church (1979, 1:322). These words foretell the future excommunication of Marie-Paule and thus anticipate — and seek to neutralize — the criticism she expects to receive because of her revelations.

Despite Auclair's media background, he did not succeed in effectively communicating the symbolism and contents of her providential revelations to the public. At that moment in 1979, the French-speaking Belgian Marc Bosquart entered the movement. He had met Auclair previously and shared his interest in millennialism and the new Army of Mary. Bosquart decided to dedicate himself to "Mary's Work" in Quebec. He had shown up in Lac-Etchemin only because of "a better understanding of the grandeur of the Mystery of the Co-Redemption which is being accomplished in Marie-Paule and through Marie-Paule." Settling in there, he himself received "revelations" from heaven about the visionary and the mysteries in her writings. While he started to explain the texts, his interpretations and recapitulations brought him in conflict with Marie-Paule, who feared for her sole and undisputed position. Nevertheless, somewhat later she realized that she had to accept him fully, as she came to the understanding that Bosquart was also an integral part of God's plan, a "prophet" of the movement:

[...] in suffering, he opened himself to what was strange but certain. Now, without his knowing it at that time, it was the Virgin Mary, as the Lady of All Peoples, instructing him in the secret hidden — and sealed — in Life of Love. ${ }^{17}$

The new cosmological theology of the movement was ultimately laid down in Bosquart's three seminal books published in 2002 and 2003. In these scriptures he describes a "total earth" constellation consisting

17) http://www.communaute-dame.qc.ca/vie-damour/VA_oeuv-col-Marc_AN.htm. 
of an "egg," within which there are superior (terrestrial and celestial) paradises and inferior worlds (purgatories, abyss), and the Earth inbetween. ${ }^{18}$ Bosquart relates Earth and the "beyonds" with Marie-Paule's concept that humans consist of three bodies: the physical body (as we know it), a psychic body ("the inferior mortal soul"), and the spiritual body ("the superior immortal soul"). In this way Bosquart developed a convergence of notions between Christianity and other mystic and religious traditions of the world, in order to do justice to the universality of the Lady, who is supposed to address and mobilize all peoples of all faiths. In his spectacular theological exegesis on Mother Mary (the Lady of All Peoples) Bosquart positions her as an equal to the Father (God). The theology implies that this Mother was incarnated in Mary and is reincarnated in Marie-Paule. ${ }^{19}$ In this system Marie-Paule is the rebirth of the Immaculate Conception and the Lady of All Peoples at the same time. He positions Marie-Paule as being of the same nature as Jesus Christ, and for him she represents the Eucharist as well. In her person Marie-Paule is then the co-redemptrix and Mother of all humans (Bosquart 2002:117-118).

The ground for that premise, Mary as co-redemptrix sharing the salvific work of Christ, is to be found in the messages which the visionary Peerdeman received earlier in Amsterdam. The concept of Mary as coredemptrix is, however, not a new one. It had already been a highly controversial theological subject in the Roman Catholic Church for centuries (De Ridder 1960). The genesis of this doctrine was, moreover, emphatically related to the presumed approach of the end of time in the Middle Ages. In the nineteenth and twentieth centuries the concept was developed further, with Mary coming to be seen primarily as the mediatrix, the mediator of grace for her son and reconciler of and for

18) Apart from the writings of Marie-Paule and Raoul Auclair's L'homme total dans la terre total (1985), inspiration for this cosmology is taken from the early nineteenthcentury visions of Anna-Katharina Emmerich and, to a lesser extent, from the medieval visions of Hildegard of Bingen. See Martel 2010.

19) The first mention of the reincarnation is to be found on the last page of Giguère's first volume, where she noted the words that God spoke to her on May 5, 1959; in a comment she explains that it concerns "mystical gifts" (Marie-Paule 1979, 1:328329). The May/June 2007 issue of their journal Le Royaume describes Marie-Paule being formally proclaimed as the mystic reincarnation of Mary on May 31, 2007; three days later Raoul Auclair was canonized under the name of Saint Raoul-Marie. 
the whole world. Proceeding from the premise that Mary would have shared in the suffering at the foot of the cross, maximalist and minimalist interpretations of the suffering discourse developed within ecclesiastical, theological, and mystical discourses. In the Amsterdam messages the role of co-redemptrix is simply regarded as a factual divine revelation, one that must lead to a new and final Marian dogma, the apogee in the process of empowering Mary as co-redeemer and messiah. ${ }^{20}$ The concept of a fifth dogma was explicitly described in the Amsterdam message of May 31, 1951. The Lady then revealed that the Father and the Son brought her into the world as co-redemptrix, and that "this will be the new and final Marian Dogma" (Messages 1999:102). Directly after this apparition, a painting of the Lady was made by the painter Heinrich Repke, representing her in her redeeming capacity as she appeared to Ida Peerdeman. In iconography too blatant to allow misinterpretation, Mary is depicted in front of the cross, to express her suffering. In this way she challenges the place of Christ on the cross and in fact - as Christ is not present - takes it over. This iconographic program, spread via millions of prayer cards, is deployed to underpin and visually inscribe the new theological concept among all peoples in the world. The Canadian Community of the Lady of All Peoples expanded the iconography with an image of both Christ and Mary depicted within the Holy Sacrament (the host) and placed above a chalice, expressing that both gave (or will give) their blood for human redemption.

These new viewpoints and doctrines show that Giguère's movement is not just religious but messianic as well. As the teachings indicate that Mary has the same nature as Christ, and Marie-Paule is Mary returned to earth as co-redemptrix, she implicitly claims to be a co-messiah as well and positions herself in fact as a co-representational second coming. The first reference to that by Marie-Paule herself, who was born significantly on September 14, Holy Cross Day, is laid down in the message that God allegedly sent to her on May 4, 1958:

20) It is counted as the fifth dogma, following the dogmas from the early church of 1) the Virgin Birth (of Christ) and 2) the Mother of God, from 1854 of 3) the Immaculate Conception, and from 1950 of 4) the Assumption of Mary. 
C'est toi, Mon enfant, qui souffres Ma Passion et qui, au nom de Ma Mère bien-aimée vas redonner le Christ au monde. ("It is you my child, who suffers My Passion and who, in the name of My beloved Mother, will give Christ back to the world.") (1979, 1:326).

She imitated Christ in his suffering, represents him, and is ready to take over his assignment.

\section{A Gendered Trinity}

Initially these events might have had in themselves little relevance within the context of my previous research into apparitional and visionary cultures, were it not that Marie-Paule had begun a comprehensive appropriation process of the Amsterdam cultus, claiming not only to be the reincarnation of Mary but also the reincarnation within the whole framework of the messages of the Amsterdam Lady of All Nations. Mary "abides" in Giguère's body (Marie-Paule 1979, 1:11). In this way Marie-Paule expanded the traditional Trinitarian doctrine by supplementing it with a gendered Immaculate Trinity, consisting of three women, including herself: Mary of Nazareth, the Immaculate Mary, and the Immaculate daughter, namely Marie-Paule. Moreover, by means of new messages — of which she stated, "The will of God passes through Marie-Paule"21 — she made known to the world that it is not the Amsterdam manifestation of Mary that is the culmination of the Marian era, as was said before, but that it is Giguère's, being herself the co-redemptrix who returned to Earth (Paul-Marie 1985:88-90; Bosquart 2003b), underpinning this claim with a vague reference to the previously-mentioned announcement of her return in 1951. With regard to the encounter she had in 1977 in Amsterdam with visionary Ida Peerdeman, also mentioned above, Marie-Paule stated that the latter would indeed have confirmed the "transfer" of the central Marian focus from Amsterdam to Lac-Etchemin. The management of the Amsterdam cultus, itself thus also strongly controversial and affected by

21) "La volonté de Dieu passe par Marie-Paule," Lac-Etchemin, interview with Sr. Chantal Buyse of the Army of Mary, October 21, 2007. 
the same Ratzinger notification, hotly denied these claims. ${ }^{22}$ So while the two movements were forbidden by the Vatican, each continued to exclude the other and declared themselves authentic - Amsterdam by declaring Marie-Paule's revelations to be false and claiming supernatural status for their apparitions, and Lac-Etchemin by professing to be the last and supreme continuation of Amsterdam and the elected place for Mary to come back to earth in person. Never before in modern visionary culture has a Marian apparition become so contestational within itself, with conflicting claims to authenticity and contradictory devotional "offshoots," ${ }^{23}$ messages, and scriptures.

\section{The Cabalistics of the Lady}

As in other millennialist and visionary milieus, the spiritual leaders of the Army of Mary state that "in our time of deep confusion, prophecy is necessary and more alive than ever." They situate their movement in a line of prophetic action that is steered from above and indispensable for those who seek salvation. They consider today's world too complex and confused to be understood by humans, and that is why, as they state, only the divine can guide humanity and create order in the earthly chaos. In this connection Marie-Paule made clear that the numbers in her own and in Bosquart's scriptures should, in an additional interpretative way, be used for explaining her mystic experiences and to present proof for those who are still in dubio (Auclair 1993:239). The case of the Army of Mary shows how the devotees involved, driven in their desire for salvation, disobey established authorities and are prone to avow new principles and dogmas. Visionary milieus are thus fully capable of diverting people from the traditional paradigms of religion. Such sectarian communities claim, for example, approval by the divine, as for them the mediated messages from Christ or Mary overrule all

\footnotetext{
22) See the episcopal letter regarding the Army of Mary of September 18, 2007: http:// www.de-vrouwe.net/english/index.html.

23) Due to the recognition by the Japanese bishop of Akita of a weeping statue of the banned Amsterdam Lady of All Nations and of apparitions and messages which the sister involved received from 1973 on, the offshoot cultus received a formal acknowledgement in 1984, when the "original" apparition in Amsterdam was still rejected by the Church.
} 
anathemas of Church officials. It is the simple argument by hierarchy. Signs and messages coming from a higher, indisputable level heaven - supersede the local bishop or the Vatican, even (or especially) when the latter disqualifies the visionary and his or her messages. They find convincing inspiration in earlier condemned persons who ultimately were rehabilitated. While the stigmatic Padre Pio was excommunicated for decades, he is now a major saint. And that is exactly what some foresee for Marie-Paule. These are interesting examples of the elastic politics and doctrinal paradigms of the Roman Catholic Church (cf. Margry 2009a).

But when the Church does support the cultus, as it does now for Amsterdam, the opinion of the hierarchy will be appropriated as validation. When in 2007 the Army of Mary was excommunicated, the Amsterdam branch hastened to reconfirm itself as a fully normalized apparitional site, despite the ongoing discussion and the never-revoked prohibitions. The harsh intervention of the Vatican and the widespread reports of it in the media created a division among the following of the Army of Mary. In headquarters and organized cohabitative living quarters they upheld their claims even more vigorously, while less-connected devotees started losing confidence.

To counter the loss of adherents or their fading faith, various partially-related discourses endorsing the apparitional logic are often constructed and instrumentalized by the leadership of an apparitional site. The "topology" of the whole transnational Lady cultus labeled the sacred places involved as unique and a logical consequence of the messages; it also pointed to a hierarchy: initially Amsterdam and subsequently Lac-Etchemin as the ultimate shrine of the Marian age. To that end the messages and devotional practices of both shrines were analyzed by their respective ideologists, finding analogies to reconfirm their authenticity. Contradictory narratives which seemingly stand in opposition to such analogies are also deployed to stress the authenticity of one's own devotion. Another important instrument to convince followers is the use of "scientific," calculative proof. By taking up the role of a theologian or academician, visionaries (or their principal followers) try to affirm that the supernatural status of the phenomenon or the veracity of the textual contents can be proven. 
In the case of the Lady of All Peoples, for example, the sacred "Quinternity" number 55,555 was later brought up as the basis for explaining the logic of the newly-introduced Marian Trinity, consisting of the Immaculate Mary, Marie-Paule, and the Holy Spirit. The combination of the Marian Trinity with the classic trinity - the Father, the Son, and the Holy Spirit - brings about a total of five "elements," as the Holy Spirit is regarded as the same for both Trinities. This ensemble is also one, as the feminine - the immaculate — is also present in God. Their explanation states that the first coming of the Immaculate Mary is symbolized by the first number five and the second coming (Marie-Paule) is represented by double fives, which represents her actions with the "True Spirit," namely the Holy Spirit of Mary, a work that started in the year 2000 and which will realize the number 555 when it is finished, when the new millennium has arrived. This kind of reasoning is thought to keep the followers convinced of the real truth they have chosen.

In their systematization the numbers are supposed to connect the cultus to its origins and to close the circle. It would set the formation of the cultus in line with what God allegedly prophesied to Giguère in 1958 about her crucifixion and reincarnation and about the existence of a Marian trinity. The full number of 55,555 then - the Quinternity is the symbol of the actions of the Lady of All Peoples with the True (Marian) Holy Spirit. The figure is presented as a holy number that symbolizes future victory over evil - evil itself symbolized in the human number of the beast (666) - and the conditional coming of the new millennium (cf. Baum 1970:49-63).

\section{Conclusion}

An analysis of the transnational cultus of our Lady of All Nations/Peoples makes clear that Catholicism, and more specifically the visionary and apparitional cultures on the fringes of that Church, is influenced by contemporary religious eclecticism and stimulated by esotericism. Modern visionary culture reflects millennialist beliefs, and in this case it shows messianic ambitions. The Lady/Giguère makes it clear that she will bring a new millennium herself, if humanity will fulfill certain 
conditions. Such progressive millennialist views find fertile soil in societies in a socio-economic, political, and religious crisis, and because of the dwindling of existential certainties on an individual level. The optimistic stance of progressive millennialism can make expressions of this kind of millennialism into successful religious movements, especially when the earth and the Church seem doomed in the eyes of the adherents. Marie-Paule Giguère thus effectively managed to take over the longstanding apparitional cultus of the Lady of All Nations and claim her own position as a vehicle for universal salvation. When the devotion was rejected by the Church, it did not seem to hinder the movement; on the contrary, the devotees created an inwardly-directed cohesion. They found sufficient support in visionary inspired logic that complies with their personal situations and which offers a direct perspective regarding salvation. When revelation and salvation are taken from the hierarchical ecclesiastical powers and situated in the "banality" of everyday life of the reincarnated Mary, they create credibility and realize an appealing perspective for those who are apart from or feel neglected by the Church of Rome. They are inclined to accept new theologies and cabalistic proofs that stretch beyond the already-deviating Amsterdam views. In the providential Marie-Paule Giguère, the devotees involved found a prophet who is both Mary and a co-redeeming messiah and who will soon realize the second millennium for all peoples and faiths, based on a new divine or cosmological plan adapted to the present world situation (cf. Martel 2010:185).

Dealing with the cultus of the Lady is complicated for the devotees and for the Church as well, as they represent two mirror-like competing movements in Europe and North America, each presenting different justifying narratives to claim their salvific goal. The Giguère movement overplayed its hand by expanding the Catholic doctrines in a heretical and esoteric manner and subsequently alienated itself from institutional and mainstream Catholicism as a sectarian group, while the debated Amsterdam cultus, stripped of some of its sharp edges, is paradoxically being reintegrated into formal Catholicism as part of the reinforcement strategy of the Roman Catholic Church. ${ }^{24}$

24) There is still a fierce international debate ongoing on the Amsterdam cultus, but the Vatican has implicitly accepted its present acknowledged status quo as presented by the bishop of Haarlem-Amsterdam, who, as a new visionary himself, came in 2002 


\section{References}

Alles, Hildegard. 2008. Doorgelicht: De Vrouwe van alle Volkeren. De verschijning van Amsterdam: Bovennatuurlijk...? Hilversum: Stichting Vaak.

Ashcraft, W. Michael. 2011. "Progressive Millennialism.” In Catherine Wessinger (ed.), Oxford Handbook of Millennialism, Oxford: Oxford University Press, 44-65.

Auclair, Raoul. 1993. La fin des temps. Quebec: Ed. Stella.

Barkun, Michael. 2003. A Culture of Conspiracy: Apocalyptic Visions in Contemporary America. Berkeley: University of California Press.

Baum, Hans. 1970. Die apokalyptische Frau aller Völker. Kommentare zu den Amsterdamer Erscheinungen und Prophezeiungen. Stein am Rhein: Christiana-Verlag.

Beinert, Wolfgang, and Heinrich Petri (eds.). 1997. Handbuch der Marienkunde, vol. 2, Regensburg: F. Pustet.

Bosquart, Marc. 2002. New Earth New Man. Lac-Etchemin: Ed. du Nouveau Monde.

- 2003a. The Immaculate, the Divine Spouse of God. Lac-Etchemin: Ed. du Nouveau Monde.

- 2003b. Marie-Paule and Co-Redemption. Lac-Etchemin: Ed. du Nouveau Monde.

Bromley, David G., and Rachel S. Bobbitt. 2011. "Visions of Mary: The Organizational Development of Marian Apparitional Movements." Nova Religio 14(3): $5-41$.

Campbell, Colin. 1972. "The Cult, the Cultic Milieu and Secularisation." A Sociological Yearbook of Religion in Britain 5:119-136. [Reprinted in Kaplan and Lööw 2002, 12-25].

De Millo, Andrew. 2007. "Six Catholic Nuns in Arkansas Excommunicated for Heresy.” The Morning News, September 26, 2007.

De Ridder, Cornelis A. 1960. Maria Medeverlosseres? De discussie in de huidige RoomsKatholieke theologie over de medewerking van de Moeder Gods in het verlossingswerk. Utrecht: Evangelische Maatschappij.

Geoffroy, Martin, and Jean-Guy Vaillencourt. 2001. "Les groupes catholiques intégristes. Un danger pour les institutions sociales?” In Jean Duhaime and GuyRobert St-Arnaud (eds.), La peur des sectes. Montréal: Editions Fides, 127-141.

Kaplan, Jeffrey, and Heléne Lööw (eds.). 2002. The Cultic Milieu: Oppositional Subcultures in an Age of Globalization. Walnut Creek: AltaMira Press.

Kruk, Ester. 2003. Zoals sneeuwvlokken over de wereld dwarrelen. De hedendaagse devotie rond Maria, de Vrouwe van Alle Volkeren. Amsterdam: Aksant.

Kselman, Thomas, and S. Avella. 1986. "Marian Piety and the Cold War in the United States." The Catholic Historical Review 72:403-424.

in a moment of prayer and mystical reflection to the insight that the Amsterdam apparitions and messages were of a supernatural kind (cf. Margry 2009b). This process endorses the conclusion of Bromley and Bobbitt (2011:30) on the development of apparitional movements in general. 
Lemm, Robert. 2003. De Vrouwe van Alle Volkeren. Amsterdamse verschijningen van bovennatuurlijke oorsprong. Soesterberg: Aspekt.

Laurentin, René, and Patrick Sbalchiero (eds.). 2007. Dictionnaire des 'apparitions' de la Vierge Marie. Inventaire des origines à nos jours. Méthodologie, bilan interdisciplinaire, prospective. Paris: Fayard, 1275-1276.

Marie-Paule [Giguère]. 1979-1987. Vie D'Amour, 15 vols. Lac-Etchemin: Vie D’Amour Inc.

Margry, Peter Jan. 1997. “Amsterdam, Vrouwe van Alle Volkeren.” In Peter Jan Margry and Charles Caspers (eds.), Bedevaartplaatsen in Nederland, vol. 1, Hilversum: Verloren, 161-170. [Also online http://www.meertens.knaw.nl/bedevaart/bol/plaats/29]

_ 2004. "Global Network of Divergent Marian Devotion.” In Christopher Partridge (ed.), Encyclopedia of New Religions: New Religious Movements, Sects and Alternative Spiritualities, Oxford: Lion Publishing, 98-102.

_ 2009a. "Paradoxes of Marian Apparitional Contestation: Networks, Ideology, Gender, and The Lady of All Nations." In Anna-Karina Hermkens, Willy Jansen, and Catrien Notermans (eds.), Moved by Mary: The Power of Pilgrimage in the Modern World, Aldershot: Ashgate, 182-199.

- 2009b. "Marian Interventions in the Wars of Ideology: The Elastic Politics of the Roman Catholic Church on Modern Apparitions." History and Anthropology 20:245-265.

Martel, Raymond. 2010. La face cachée de l'Armée de Marie. Anjou, Quebec: Fides.

Matter, E. A. 2001. "Apparitions of the Virgin Mary in the Late Twentieth Century: Apocalyptic, Representation, Politics.” Religion 31:125-153.

Messages of the Lady of All Nations, The New Edition. 1999. Amsterdam: The Lady of All Nations Foundation.

Paul-Marie, Mère. 1985. Lac-Etchemin. La Famille des Fils et Filles de Marie. Limoilou: Vie D'Amour.

Wessinger, Catherine. 2000. "Progressive Millennialism.” In Richard A. Landes (ed.), Encyclopedia of Millennialism and Millennial Movements, New York: Routledge, 332-333.

Wojcik, Daniel. 2011. "Avertive Apocalypticism." In Catherine Wessinger (ed.), Oxford Handbook of Millennialism, Oxford: Oxford University Press, 66-88.

Zimdars-Swartz, Sandra L. 1991. Encountering Mary: Visions of Mary from La Salette to Medjugorje. Princeton: Princeton University Press. 